\title{
Consumers' Preferences towards Meat and Meat Products with Traceability Systems in Klang Valley, Malaysia
}

\author{
Hani Nabila Basri, Nolila Mohd Nawi, Nitty Hirawaty Kamarulzaman, \\ Mad Nasir Shamsudin \\ Dept. of Agribusiness and Bioresource Economics - Faculty of Agriculture-Universiti Putra Malaysia, \\ Serdang, Selangor, Malaysia
}

\begin{abstract}
Nowadays, consumers' concerns towards food safety have significantly increasing and they tend to generally aware about their health. This concern has become particularly serious because of food scandal and countless cases that happened around the world. These scandals lead to negative effect and perception to consumers, food companies and also both supply and demand chain. There are a lot of strategies by agriculture food industries to increase food safety such as developed and implemented traceability systems among consumers. However, the awareness level towards traceability system among Malaysian consumers was low. The aim of this research is to determine consumers' preferences towards meat and meat products with traceability systems in Klang Valley, Malaysia. This study was based on a quantitative approach and the primary data were collected using structured questionnaire via face to face interview with 503 respondents. Data collected were analyzed using descriptive analysis and chi square analysis. The results of the study indicated that majority of the consumers prefer to use traceability systems and they think traceability systems are important when buying meat and meat products. In addition, the results of chi-square analysis revealed that socio-demographics profile such as gender, race, marital status, educational level, income and household size has an association with respondent's preferences towards meat and meat products with traceability systems. Traceability systems have the potential to be implemented if the government, meat producers, marketers, and retailers have a better understanding towards preference of consumers towards meat and meat products with traceability systems. It also allows them to start planning for the implementation of traceability system in near future as a strategy to improve their service which in line with the increasing of food safety awareness among consumers.
\end{abstract}

KEYWORDS: consumers' preferences, meat traceability, traceability, traceability systems, chi-square analysis

\section{INTRODUCTION}

Traceability systems nowadays are basically a system that has been developed to improve food safety problems and foodborne illness that recently happened around the world. It also developed to meet consumer demands in terms of consistent supply of high quality and safer food products (Giraud and Halawany, 2009). This is because there are countless cases recorded globally regarding food safety such as food scandals that occurred in Europe which is Bovine Spongiform Encephalophaty (BSE), the milk adulterated in China and foodborne illness or disease that still happening around the world. These scandals lead to negative perception among consumers and give damaging impacts to the food companies and also to both supply and demand chain (Hansstein, 2014). As a result, the assurance from consumers towards food safety decreases as the consumers feel unsure on the quality of the taken food, particularly meat and meat products (Hansstein, 2014). Traceability systems has been impelemented in many countries such as China, United States of America (USA), and Japan (Lichtenberg et al., 2008).

Recently, consumers in Malaysia are really concerns about their health and safety issues but the awareness level towards traceability systems among consumers in Malaysia is still low. Moreover, this system has not been developed in Malaysia.This is due to the implementaton of this system required high cost for start up and needs staff who have applicable skills to operate this systems (Uchida et al., 2009). Besides, despite of high awareness of consumers towards food safety, there arecertain consumers that have no intention to aware the products information on the purchased food products. These consumers are using the sales person as a substitute of traceability to make a decision in purchasing food products, especially meat and meat products. Furthermore, there are countless cases and issues discovered by the Malaysian authorities and reported by consumers regarding food safety. For instance, there are several cases occured in Malaysian supermarket and retail store where consumers found non-Halal Deoxyribonucleic Acid (DNA) in ingredient produced by the food 
manufacturer. There also some issues regarding fake Halal logo in premises or product packaging where all of this cases can create abad perception towards entire food system (Samsi et al.,2012).

This food crisis and all negative cases affected theproducers, marketers and retailersalong the food chain. Meanwhile, the demand of meat and meat products in Malaysia are significantly increasing year by year especially for chicken meat, beef meat and lamb meat (Ministry of Agriculture,2011).Implementations of traceability systems are needed for giving extra quality towards meat and meat products to consumers for eat and consume. It alsocan assist consumers to differentiate between a good quality and low quality meat and meat products in the market by providing them with the required information. Therefore, consumers tend to put their trust and confidencetowards the labelling information provided by the producer, supplier or retailer (Lichtenberet al., 2008). The collaboration between the government and the meat market are necessary in order to provide accurate information to customers regarding the processing of meat and meat products in the supply chain, the Halal certificate, and quality of meat and meat products. As a result, Malaysia meat market can develop rapidly in terms of exports and imports of meat and meat products (Kamarudin et al., 2013). Thus, the aim of this research is to explore consumers' preferences towards meat and meat products with traceability systems in Klang Valley, Malaysia.

\section{MATERIALS AND METHODS}

A survey was conducted in order to collect survey information about consumers' preferences towards meat and meat products with traceability systems in Klang Valley. A structured questionnaire was designed and divided into four sections. The questionnaire was designed by using a Likert Scale of 1 to 7 (1 representing strongly disagree and 7 standing for strongly agree) in order to measure consumers' preferences towards meat and meat products with traceability systems. Primary data were collected using structured questionnaire via face to face interview with 503 respondents in Klang Valley. The collected data were analyzed using descriptive analysis and chi square analysis. Descriptive analysis was used to describe the basic features of the data in this study. It described the respondent's profile and their preferences with regard to traceability systems of meat and meat products. Meanwhile, chi-square analysis was carried out to identify the association between sociodemographic profile and respondents preferences towards meat and meat products with traceability systems. These elements are crucial for the implementation of traceability systems in Malaysia.

\subsection{Descriptive Analysis}

\section{RESULTS AND DISCUSSION}

Descriptive analysis was used to analyze the results of the socio demographic profile of the respondents of this study. The demographic profile includes gender, race, marital status, occupation, educational level, religion, age and income. Based on the Table 1, indicates majority of the respondents were females, $56 \%$ compared to males, 44\%. Majority of the respondents' are Malay (54.6\%) followed by Chinese $(24.5 \%)$. Respondents aged between 31 to 40 years old are majority $(42.5 \%)$ being interviewed. Only $7.4 \%$ of respondents aged more than 60 years old. From five categories of educational level, respondents seem to have bachelor with $47.1 \%$ followed by master $(18.5 \%)$. More than half of respondents were married with monthly income gained was more than RM9000 with $2.6 \%$. The lowest monthly income is below than RM3000 with $29.4 \%$.

Table 1: Respondents' Socio-Demographic Profiles

\begin{tabular}{|l|c|c|}
\hline Profile & $\begin{array}{c}\text { Frequency } \\
\text { (n) }\end{array}$ & Percentage (\%) \\
\hline Gender & & 44.0 \\
\hline Male & 221 & 56.0 \\
\hline Female & 282 & \\
\hline & & 54.6 \\
\hline Race & & 24.5 \\
\hline Malay & 275 & 19.9 \\
\hline Chinese & 123 & 1.0 \\
\hline Indian & 100 & \\
\hline Others & 5 & 24.0 \\
\hline & & 69.0 \\
\hline Marital Status & 121 & 7.0 \\
\hline Single & 346 & \\
\hline Married & 36 & \\
\hline Widow/Widower & & \\
\hline
\end{tabular}




\begin{tabular}{|l|c|c|}
\hline & & \\
\hline Occupation & & 29.2 \\
\hline Fulltime working & 147 & 20.5 \\
\hline Self employed & 103 & 31.6 \\
\hline Professional & 159 & 9.5 \\
\hline Retired & 48 & 5.0 \\
\hline Housewife & 25 & 4.2 \\
\hline Student & 21 & \\
\hline & & \\
\hline Household Size & & 35.0 \\
\hline 1 to 3 & 176 & 52.9 \\
\hline 4 to 6 & 266 & 10.9 \\
\hline 7 to 9 & 55 & \\
\hline Educational Level & & 4.37 \\
\hline PMR, SPM, STPM & 22 & 11.5 \\
\hline Certificate & 58 & 11.9 \\
\hline Diploma & 60 & 47.1 \\
\hline Bachelor & 237 & 18.5 \\
\hline Master & 93 & 6.56 \\
\hline Phd & 33 & \\
\hline
\end{tabular}

Results of the study in Table 2 indicated that majority of the respondents never heard about traceability systems with $36.6 \%$ and only $13.3 \%$ know about traceability systems very well. Even though majority of the respondents does not know about traceability systems, they think traceability systems are important when buying meat and meat products by planning to use it in the future. Most of them think that Halal Certification is one of main factor that they will consider when buying meat and meat products with traceability systems that accounted for $43.6 \%$. They also choose to use traceability systems if quality standard of the meat and meat products are provided $(43.0 \%)$. Other than that, they choose ingredients and nutrition as other important reasons to use traceability systems $(38.6 \%)$ followed by country of origin $(33.0 \%)$ and transparency $(28.8 \%)$. Next, majority of the respondents are planning to use traceability systems in the future if the systems can provide all the information required with 418 respondents $(83.6 \%)$ compared to respondents who declined to use it in future $(13.4 \%)$.It shows that the introduction of traceability systems in Malaysia has the potential to be accepted by the Malaysian consumers.

Table 2: Respondents' Awareness and Preferences towards Meat and Meat Products with Traceability Systems

\begin{tabular}{|l|c|c|}
\hline Statements & Frequency & Percentage (\%) \\
\hline Awareness towards Traceability Systems & & 36.2 \\
\hline Never Heard & 181 & 26.4 \\
\hline Heard about it but know a little & 131 & 24.2 \\
\hline Heard about it but not sure & 121 & 13.4 \\
\hline Know very well & 67 & \\
\hline $\begin{array}{l}\text { Important of Meat and Meat Products with } \\
\text { Traceability Systems }\end{array}$ & & 33.0 \\
\hline Country of origin & 165 & 38.6 \\
\hline Ingredients and nutrition & 193 & 43.6 \\
\hline Halal certificate & 218 & 31.2 \\
\hline Date information & 156 & 43.0 \\
\hline Quality & 215 & 28.8 \\
\hline Transparency & 144 & 83.1 \\
\hline Planning to use in future & & 16.9 \\
\hline Yes & 418 & \\
\hline No & 82 & \\
\hline
\end{tabular}

\subsection{Chi Square Analysis}

Results of chi-square analysis to determine the association between consumers' preferences towards meat and meat products with traceability systems and their socio-demographic characteristics is presented in Table 2. The results indicated that some of the socio-demographic characteristics of respondents showed a significant relationship with consumers' preferences towards meat and meat products with traceability systems. Results in Table 2 revealed that out of nine variables only six variables have shown a significant relationship at $5 \%$ significant level $(\alpha=0.05)$. The six variables are gender, race, income, educational level, marital status, and 
household size. As for gender, it has been reported that women are more likely prefer to buy meat and meat products with traceability systems compared to men. This finding is supported by studies from Dickinson and Bailey (2002) that revealed females are more likely willing to pay higher prices for meat and meat products. Previous study also showed gender has a significant influence on food products (Ahmad and Jundi, 2010; Govindasamy and Italia, 1999). Besides that, as regards to race, the Malay consumers were comparatively more prefer to use traceability systems than other races in Malaysia because most of them are Muslim and they very particular about Halal certificate towards meat and meat products. This finding is supported by Kamaruddin $e t$ al., (2012) that discovered most of Malay respondents are searching for Halal meat and meat products in the market with Halal certificate. As regard to income, most of the respondents with income less than RM3000are preferred to purchase meat and meat products with traceability system. As reported by Zhou et al., (2010), respondents with average income were demand a good quality meat with affordable prices. While, respondent with degree educational level tend to be more prefer to choose and purchase meat and meat products with traceability systems because of their knowledge towards this systems. Married people are generally more preferred to purchase meat and meat products with traceability systems especially when the household size is increasing and having kids in their house.

\begin{tabular}{|c|c|c|c|c|}
\hline \multicolumn{5}{|c|}{$\begin{array}{c}\text { Table 3: Relationship between Preference toward Traceability Systems and Respondents } \\
\text { Profiles }\end{array}$} \\
\hline Variables & Chi square value & df & Significant & Decision \\
\hline Age & $0.399^{\mathrm{a}}$ & 1 & 0.399 & Fail to Reject $\mathrm{H}_{0}$ \\
\hline Gender & $21.140^{\mathrm{a}}$ & 3 & $0.000^{* *}$ & Reject $\mathrm{H}_{0}$ \\
\hline Race & $12.729^{\mathrm{a}}$ & 2 & $0.002 * *$ & Reject $\mathrm{H}_{0}$ \\
\hline Income & $10.967^{\mathrm{a}}$ & 5 & $0.052^{*}$ & Reject $\mathrm{H}_{0}$ \\
\hline Education & $21.183^{\mathrm{a}}$ & 4 & $0.000^{* * *}$ & Reject $\mathrm{H}_{0}$ \\
\hline Marital status & $11.062^{\mathrm{a}}$ & 4 & $0.026^{*}$ & Reject $\mathrm{H}_{0}$ \\
\hline Occupation & $1.898^{\mathrm{a}}$ & 3 & 0.594 & Fail to Reject $\mathrm{H}_{0}$ \\
\hline Religion & $7.966^{\mathrm{a}}$ & 5 & 0.158 & Fail to Reject $\mathrm{H}_{0}$ \\
\hline Household size & $4.980^{\mathrm{a}}$ & 1 & $0.028^{*}$ & Reject $\mathrm{H}_{0}$ \\
\hline \multicolumn{5}{|c|}{$\begin{array}{l}\text { Note: } n=503 \\
* * \text { Significant at } 1 \% \text { level of significance, *Significant at } 5 \% \text { level of significance } \\
\text { Source : Survey (2016) }\end{array}$} \\
\hline
\end{tabular}

\section{CONCLUSION}

Overall, the main purpose of this research is to explore on consumers' preferences towards meat and meat products with traceability systems. The attitude of respondents towards traceability systems is generally positive in terms of benefit and important of this system such as quality of meat and meat products, safety, country of origin and information dates are given. Meanwhile, the findings of this study also revealed that sociodemographic profile such as gender, race, income, education, marital status and household size has an association with Malaysian consumers' preferences towards meat and meat products with traceability systems. Addressing some of the local issues, respondents' concerns while highlighting the advantages of traceability systems, it can help to improve the attitude, awareness and preferences of customers towards meat and meat products with traceability systems. The findings of this study may be useful as an initial guide to the supply chain players in the meat industry on the preferences and factors needed to be addressed when considering the implementation and development of traceability systems in Klang Valley, Malaysia.

\section{ACKNOWLEDGEMENTS}

The authors would like to thank Universiti Putra Malaysia (UPM) for providing financial assistance under Universiti Putra Malaysia Grant Scheme (GP-IPS/2016/9506900) to perform this research.

\section{REFERENCES}

[1] Ahmad, S. N. B. \& Juhdi, N. (2010). Organic Food: A study on demographic characteristics \& factor influencing purchase intentions among consumers. International Journal of Business and Management, 5(2), 105-118.

[2] Giraud, G. \& Halawany, R. (2006). Consumers' perception of food traceability in Europe. International Food and Agribusiness Management Association, World Food and Agribusiness Symposium Buenos Aires, Argentina, Buenos Aires, Argentina, 98. 
[3] Govindasamy, R. \& Italia, J. (1999). Predicting willingness-to-pay a premium for organically grown fresh produce. Journal of Food Distribution, 30, 44-53.

[4] Hansstein, F.V. (2014). Consumer knowledge and attitudes towards food traceability: A comparison between the European Union, China and North America. International Conference on Food Security and Nutrition IPCBEE, 67.

[5] Kamaruddin, R., Iberahim, H. \&Shabudin, A. (2013). Willingness to pay for Halal logistics.

a. Environment-Behaviour Studies (cEBs), Faculty of Architecture, Planning Surveying,UniversitiTeknologi MARA, 722-729.

[6] Kamaruddin, R., Shabudin, A. \&Iberahim, H. (2012). Halal compliance critical control point (HCCP) analysis of processed food. Proceedings of 2012 IEEE Business, Engineering \& Industrial Applications Colloquim, 5-7 April 2012, Kuala Lumpur.

[7] Lichtenberg, L., Heidecke, S. J. \& Becker, T. (2008). Traceability of meat: Consumers' associations and their willingness-to-pay. Congress of the European Association of Agricultural Economists - EAAE 2008.

[8] Ministry of Agriculture and Agro-Based Industries. (2011). Retrieved from http://www.moa.gov.my/

[9] Opara, L. U. \&Mazaud, F. (2001). Food traceability from field to plate. Outlook on agriculture, 30(4), 239-247.

[10] Samsi, S. Z. M., Ibrahim, O. \&Tasnim, R. (2012). Review on knowledge management as a tool for effective traceability system in Halal food industry supply chain. Journal of Research and Innovation, 1, 78-85.

[11] Uchida, Y., Matsimo, S., Tamaki, T. \& Ito, T. (2009).A new traceability system for SMEs with open source software. WSEAS Transactions on Business and Economics, 6(1), 1-10. 